\title{
Crystalline Inclusions in Diamonds in the Northeast of the Yakutian Diamondiferous Province
}

\author{
Sobolev, N.V. ${ }^{1}$, Yefimova , E.S. ${ }^{1},{ }^{1}$ Koptil, V.I. ${ }^{2}$
}

1. Institute of Mineralogy and Petrography, Siberian Branch of Russian Academy of Sciences, Novosibirsk, 630090, Russia

2. Almazy Rossii-Sakha Co Ltd, Mirny, 678170, Sakha, Russia

By convention the northeastern part of the Yakutian Diamondiferous Province is a territory situated north to the Arctic Circle. Only one highly diamondiferous kimberlite field is known from there - the Muna field. The rest kimberlite fields, amounting more than 15 , on this territory contain little or no diamonds. Nevertheless, for a long time diamonds have been sampled and explored from recent alluvial deposits and some gravelites and conglomerates of both Mesozoic and Paleozoic ages throughout the territory. Among these sources the Ebelyakh placer deposit is worthy of note.

Results of comparative analysis of the occurrence of the diamonds containing inclusions of ultramafic (U) and eclogitic (E) types of paragenesis (Sobolev, 1974) were first generalized for more than 6000 diamonds with inclusions (Yefimova, Sobolev, 1977) from kimberlite mines (Mir, Udachnaya, Aikhal, and Sytykanskaya) and alluvials (Anabar and Lena regions). An important peculiarity was revealed: the E-type orange garnets from the alluvial diamonds dominate about by two orders of magnitude over those from the pipe diamonds. The alluvial diamonds are also shown to contain a great number of olivine inclusions, with all colorless inclusions visually identified as olivine.

We present here the results of examination of inclusion compositions from a representative collection covering the whole territory divided not into two, as earlier, but into four regions: Anabar, Lena, Lower-Olenek, and Muna-Tyung. About 300 diamonds were selected for detailed examination. First of all, these were diamonds containing either garnet inclusions or two and more mineral phases.

The inclusion-containing diamonds are mainly rounded dodecahedral crystals, though octahedra, transitional-form crystals, intergrowths, and various twins are present among them. Cuboids total to less than $1 \%$. The crystals studied are mainly $2-4 \mathrm{~mm}$ in size. The inclusions extracted are, as a rule, negative diamond crystals, distorted to a various degree.

Garnet inclusions were liberated and analysed from about 130 diamonds. More then 20 of them are pyropes with variable $\mathrm{Cr}_{2} \mathrm{O}_{3}$ (3.4-14.6 wt.\%) and $\mathrm{CaO}$ (0.85-5.74 wt.\%) contents. E-type garnets of variable composition are typical of studied collection (see Figure). Some of them coexist with coesite, sometimes showing heterogeneities in the composition between several grains in a single diamond (Sobolev et al., 1976). Two garnets coexist with kyanite. In general almost all possible varieties of E-type parageneses demonstrating also the presence of $\mathrm{Na}_{2} \mathrm{O}$ in garnets were detected (Sobolev, 1983). Some rare E-type minerals such as kyanite, coesite (and retrograde quartz), sanidine were found in studied diamonds. Mg-wüstite is among the most unusual inclusions and was found in two alluvial diamonds. Most of these eclogitic diamonds have a wide anomalously negative range of carbon isotope composition (Galimov, 1984). Clinopyroxenes represented both by chrome diopsides and omphacites were studied. Omphacites contain variable $\mathrm{Na}_{2} \mathrm{O}$ from 2.7 up to $11.1 \mathrm{wt} . \%$, containing more than $70 \mathrm{~mol} \%$ of jadeite. Olivines are typical forsterites with the average Fo close to 92.5. Chromites and enstatites are similar to the same minerals from worldwide diamonds (Meyer, 1987).

Only U-type inclusions - chromite, olivine, and Ca-poor Cr-pyrope - were established in 11 diamonds from two pipes (Ruslovaya and Leningrad) of, supposedly, Triassic age in the Anabar region. The Dianga diamondiferous pipe of Mesozoic (156 $\pm 8 \mathrm{Ma}$ ) zircon age (W.Griffin, personal communication), is situated in the Kuoika field of the Lower-Olenek region, near the known barren 
kimberlite pipes of similar age (148-151 Ma, Davis et al., 1980), including the Obnazhennaya pipe. This is one of a few pipes situated north of $70^{\circ} \mathrm{N}$ from which inclusions in diamonds have been studied. Fourteen inclusions of clinopyroxene and eight inclusions of garnet, as well as single inclusions of picroilmenite and altered enstatite have been identified in 18 severely corroded dodecahedral diamond crystals. Garnets from Dianga diamonds are characterized by a stable elevated $\mathrm{Mg}$ content (67.1-74.0 mol.\%), moderate $\mathrm{CaO}$ (4.14-6.15 wt.\%), and stable admixture of $\mathrm{Cr} 2 \mathrm{O} 3$ (0.12-0.64 wt.\%), all these discriminate them from typical E-type garnets. Pyroxenes, coexisting with garnets in some samples, are characterized by great variations in $\mathrm{Na} 2 \mathrm{O}$ content (2.64-5.50 wt.\%). The presence of altered enstatite and indicated features of the garnets permits the whole sample of inclusions to be referred to the websterite-pyroxenite paragenesis, intermediate between the U- and E-types (Sobolev, 1983).

The wide range in garnet compositions with a number of plots occupying almost empty parts of $\mathrm{Ca}$ $\mathrm{Mg}-\mathrm{Fe}$ diagram compiled by Meyer (1987) is typical of studied diamond inclusions. High Ca-garnets including that coexisting with kyanite as well as a number of garnets plotted as transitional compositions between U- and E-types are of significance. The latter confirm the significance of websterite-pyroxenite assemblage not only at the shallower levels of the lithosphere (Sobolev, Kharkiv, 1976) but also within the diamond stability field of the studied region.

Comparison of inclusions in diamonds from placers and kimberlites of the same regions suggests that these kimberlites could not be the source for the bulk of the placer diamonds. The extremely diverse composition of the garnets, going beyond the scope of the generalized worldwide data (Meyer, 1987), as well as the steadily increased content of the E-type garnets compared with the Utype garnet in diamonds are evidence of multiplicity of sources for diamonds in this region, which, supposedly, belong to the kimberlite and/or lamproite type.

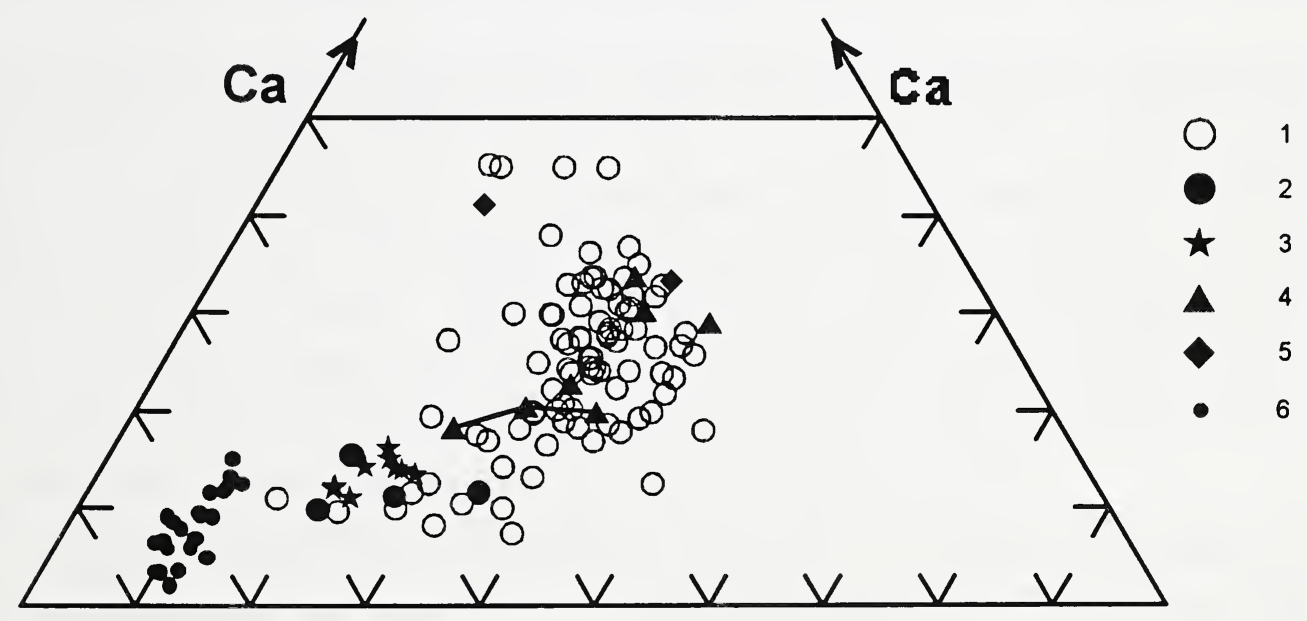

Mg

Figure. Garnet inclusions in diamonds from Northeastern part of the Siberian Platform plotted in terms of atomic Ca-Mg-Fe ${ }^{t}$. Garnets of E-type (1), of wesbsterite-pyroxenite type (2), from Dianga diamonds (3); coexisting with coesite (4), coexisting with kyanite (5), of U-type (6). 


\section{References}

Davis, G.L., Sobolev , N.V., Kharkiv, A.D., 1980, New data on the age of Yakutian kimberlites obtained by the U-Pb method on zircons (in Russian): Dokl. Akad. Nauk SSSR, v. 254, p. 175-179. Galimov, E.M., 1984, Variations of isotopic composition of diamonds and their relation to the conditions of diamonds formation (In Russian): Geokhimiya, N 8, p. 1091-1117.

Gurney, J.J., 1989, Diamonds. In: J. Ross (ed). Kimberlites and Related Rocks: Geol. Soc. Of Australia Spec. Publication, 14, p. 935-965.

Meyer, H.O.A., 1987, Inclusions in diamonds. In: P.H.Nixon (ed). Mantle Xenoliths: John Wiley and Sons, Chichester, England.,p. 501-522.

Sobolev, N.V., 1974, Deep-seated inclusions in kimberlites and the problem of the composition of the Upper Mantle (in Russian): Novosibirsk, Nauka, 263 p. English Translation by D.A.Brown, F.R.Boyd (ed), 1977, AGU, Washington D.C., 279 p.

Sobolev, N.V., 1983, Parageneses of the diamonds and the problems of mineral formation in deepseated conditions (in Russian): Zap. Vses. Miner. Obshch., v. 112, p. 389-397.

Sobolev, N.V., Kharkiv A.D., 1976, Petrology of xenoliths in kimberlite pipes and the Upper Mantle (in Russian). In: V.S.Sobolev (ed). The Problems of Petrology: Moscow, Nauka, p. 167-172.

Sobolev, N.V., Lavrent'ev, Y.G., 1971, Isomorphic sodium admixture in garnets formed at high pressures.: Contrib. Miner. Petrol., v. 31, p. 1-12.

Sobolev, N.V., Yefimova, E.S., Koptil, V.I., Lavrent'ev, Y.G., Sobolev, V.S., 1976. Inclusions of coesite, garnet and omphacite in diamonds of Yakutia - first find of coesite paragenesis (in Russian): Dokl. Akad. Nauk SSSR, v. 230, p. 1442-1444.

Yefimova, E.S., Sobolev, N.V., 1977, Abundance of crystalline inclusions in Yakutian diamonds (in Russian): Dokl. Akad. Nauk SSSR, v. 237, p. 1475-1478. 